\title{
PHYSICAL, CHEMICAL, AND BIOLOGICAL SOIL ATTRIBUTES UNDER ANALOG AGROFORESTRY SYSTEM AND PASTURE SITES
}

\author{
Rodrigo Camara ${ }^{1}$, Gilsonley Lopes dos Santos ${ }^{1}$, Camila Santos da Silva ${ }^{1}$, Cristiane Figueira da Silva ${ }^{1}$, \\ Gabriel dos Santos de Aguiar ${ }^{1}$, Marcos Gervasio Pereira ${ }^{2}$ *

\begin{abstract}
${ }^{1}$ Federal Rural University of Rio de Janeiro, Postgraduate Program in Environmental and Forest Sciences, Seropédica, Rio de Janeiro, Brazil - rcamara73@gmail.com; leylopes85@hotmail.com; milasdas@gmail.com; cfigueirasilva@yahoo.com.br; gabriel.bio12@yahoo.com.br
\end{abstract} \\ ${ }^{2}$ Federal Rural University of Rio de Janeiro, Department of Soils, Seropédica, Rio de Janeiro, Brazil - mgervasiopereira01@gmail.com*
}

Received for publication: 17/01/2018 - Accepted for publication: 02/08/2019

\begin{abstract}
Resumo
Atributos físicos, químicos e biológicos do solo sob áreas de sistema agroflorestal análogo e pastagem. Sistema agroflorestal regenerativo análogo é um tipo de sistema agroflorestal em que espécies arbóreas que melhoram as condições microclimáticas e edáficas, para facilitar a regeneração natural de florestas suprimidas, são empregadas. Este estudo objetivou avaliar o impacto de uma área com sistema agroflorestal regenerativo análogo, sobre os atributos físicos, químicos, e biológicos. Testou-se a hipótese de que alguns destes atributos podem ser utilizados como indicadores da melhoria da qualidade do solo, na comparação com uma área de pastagem manejada. Em outubro de 2016 (final da estação seca), foram realizadas coletas de amostras de solo $(0-5,5-10 \mathrm{~cm})$ e da comunidade da fauna do solo, por meio de armadilhas de queda. Os atributos abundância total, riquezas média e total, uniformidade e diversidade da comunidade da fauna do solo, além de umidade gravimétrica, conteúdo de areia, $\mathrm{pH}$, cálcio, magnésio e soma de bases trocáveis foram maiores na área de sistema agroflorestal regenerativo análogo e, portanto, indicaram a melhoria da qualidade do solo. Os grupos Coleoptera, Diptera, Gastropoda, Hymenoptera, Isopoda, Lepidoptera, Poduromorpha, Symphypleona, Pseudoscorpionida, Lepidoptera e larvas de Coleoptera, de Diptera, de Lepidoptera e de Neuroptera são os grupos taxonômicos que foram favorecidos na área de sistema agroflorestal regenerativo análogo.

Palavras-chave: fauna edáfica; fertilidade do solo; indicadores de qualidade edáfica.
\end{abstract}

\begin{abstract}
Analog agroforestry system uses native tree species to improve soil conditions and the microclimate of degraded areas. This study aimed to assess the impact of analog agroforestry on physical, chemical, and biological soil attributes. We tested the hypothesis that some of these attributes can be used as indicators of soil quality improvement compared to a managed pasture area. Two experimental sites were selected, an analog agroforestry site and a pasture site. In October 2016 (end of the dry season), soil samples were collected from the $0-5$ and $5-10 \mathrm{~cm}$ depths and the soil fauna community was sampled using pitfall traps. The analog agroforestry system led to increased total abundance, total richness, mean richness, evenness, and diversity of the soil fauna community as well as higher gravimetric soil moisture, sand content, $\mathrm{pH}$, calcium, magnesium, and sum of exchangeable bases, which are good indicators of soil quality. Adults of Coleoptera, Diptera, Gastropoda, Hymenoptera, Isopoda, Lepidoptera, Poduromorpha, Symphypleona, Pseudoscorpionida, Lepidoptera and larvae of Coleoptera, Diptera, Lepidoptera, and Neuroptera were the most abundant taxonomic groups in the analog agroforestry system.

Keywords: soil fauna; soil fertility; soil quality indicators.
\end{abstract}

\section{INTRODUCTION}

Soil management practices, including the choice of plant cover, can positively or negatively influence the physical, chemical, and biological attributes of soil (LOURENTE et al., 2007; CAMARA et al., 2012; BARETTA et al., 2014; CABRERA-DÁVILA et al., 2017). Agroforestry systems, as compared with monocultures, have been shown to enhance soil quality, nutrient cycling, carbon sequestration, and biodiversity (FÁVERO et al., 2008). In agroforestry systems, trees and shrubs are cultivated in combination with agricultural crops and/or livestock production. A wide range of economic activities can be practiced using this system, contributing to the social,

FLORESTA, Curitiba, PR, v. 50, n. 1, p. $887-896$, jan/mar 2020.

Camara, R. et.al.

ISSN eletrônico 1982-4688

DOI: $10.5380 / r f . v 50$ i1.57476 
economic, and environmental sustainability of the agricultural sector (SCHEMBERGUE et al., 2017). These benefits can stimulate the adoption of agroforestry, especially in areas degraded by anthropic action (JOSE, 2012).

Agroforestry systems can be designed to mimic native forest structure and function. These systems are called analog agroforestry, analog forestry, or successional agroforestry. As the tree canopy becomes denser, some agricultural crops can no longer be cultivated. From this point on, natural regeneration may take place (FÁVERO et al., 2008), since tree species contribute to the improvement of soil conditions.

Fabaceae species, for instance, contribute to natural regeneration because of their association with nitrogen-fixing bacteria. Fabaceae plants increase the performance (SOUZA; PIÑA-RODRIGUES, 2013) and soil fertility of analog agroforestry systems (DIAS et al., 2006) by producing leaf litter with low lignin/ $\mathrm{N}$ ratio, which favors the release of nutrients to the soil (DUARTE et al., 2013). Cultivation of Fabaceae species has a positive effect on the diversity and density of the soil fauna community, including Oligochaeta, Coleoptera, Araneae, and Formicidae individuals, an important factor for nutrient cycling (DIAS et al., 2006).

Limited data are available on the impact of analog agroforestry on soil attributes of degraded areas. This study aimed to fill this research gap by comparing the physical, chemical, and biological attributes of soils under analog agroforestry and pasture and by identifying soil quality indicators for analog agroforestry systems.

\section{MATERIAL AND METHODS}

The study was conducted in an agroecological farm (Fazendinha Agroecológica Km 47), which is part of an integrated agroecological production system (SIPA) managed by EMBRAPA Agrobiology, PESAGRO Rio, and the Federal Rural University of Rio de Janeiro. The farm is located in the municipality of Seropédica $\left(22^{\circ} 44^{\prime} 38^{\prime \prime} \mathrm{S} 43^{\circ} 42^{\prime} 27^{\prime \prime} \mathrm{W}, 26 \mathrm{~m}\right.$ above sea level), Rio de Janeiro, Brazil. The climate is classified as Aw, characterized by dry winters and wet summers, according to the Köppen climate classification (ALVARES et al., 2013). The average annual rainfall is $1,213 \mathrm{~mm}$, occurring mainly between November and March. The average annual temperature is $23.9^{\circ} \mathrm{C}$ (CARVALHO et al., 2011), and the original vegetation is Semideciduous Tropical Forest (CORRÊA NETO et al., 2014).

Two sites were studied: a pasture with Red Yellow Acrisol and an analog agroforestry system with haplic Planosol. Pannicum maximum and Brachiaria brizantha are grown in the pasture site, which surrounds the analog agroforest. The analog agroforestry site $\left(6000 \mathrm{~m}^{2}, 200 \times 30 \mathrm{~m}\right)$ was used for pasture (Panicum maximum) until February 2005, when the analog agroforestry system was implemented (MARTINS et al., 2019). The land was plowed and mechanically graded, and seeds and seedlings of exotic forest species and Atlantic Forest species were planted (Table 1).

Table 1. Species cultivated in the early-stage analog agroforestry system site, Seropédica, Rio de Janeiro, Brazil. Tabela 1. Espécies empregadas na instalação da área de sistema agroflorestal regenerativo análogo, Seropédica, RJ, Brasil.

\begin{tabular}{llll}
\hline Use & \multicolumn{1}{c}{ Family } & \multicolumn{1}{c}{ Scientific name } & Plant spacing $(\mathrm{m} \times \mathrm{m})$ \\
\hline Firewood and "fertilizer" plant & Fabaceae & Acacia angustissima & $6 \times 5$ \\
\hline & & Albizia lebbeck & $6 \times 5$ \\
& & Albizia samam & $5 \times 5$ \\
& & Enterolobium contortisiliquum & $14 \times 16$ \\
& & Lonchocarpus guilleminianus & $5 \times 6$ \\
& & Mimosa artemisiana & $5 \times 6$ \\
& & Piptadenia gonoacantha & $5 \times 6$ \\
& & Pterogyne nitens & $6 \times 5$ \\
& & Schizolobium parahyba & $14 \times 16$ \\
& Meliaceae & Trichilia hirta & $6 \times 5$ \\
& Rhamnaceae & Colubrina glandulosa & $6 \times 5$ \\
& Anacardiaceae & Schinus terebentifolium & $6 \times 12$ \\
\hline Bimber and other & Bignoniaceae & Spararattosperma leucanthun & $6 \times 10$ \\
& Bixaceae & Bixa orelana 5 \\
& Bombacaceae & Chorisia speciosa & $6 \times 5$ \\
& Compositae & Elephantopus scaber & $14 \times 14$ \\
& Palmae & Syagrus romanzoffiana & $6 \times 12 \times 14$ \\
& Sterculiaceae & Guazuma ulmifolia & $6 \times 5$ \\
\hline Fruit crop & Bromeliacea & Ananus comosus & $1 \times 0,4$ \\
\hline & Fabaceae & Inga semialata & $4 \times 5$ \\
& Moraceae & Morus nigra & $4 \times 5$ \\
\hline
\end{tabular}




\begin{tabular}{|c|c|c|c|}
\hline & $\begin{array}{l}\text { Musaceae } \\
\text { Myrtaceae } \\
\text { Palmae }\end{array}$ & $\begin{array}{l}\text { Musa paradisiaca } \\
\text { Eugenia uniflora } \\
\text { Syzygium cumini } \\
\text { Cocos nucifera }\end{array}$ & $\begin{array}{l}3 \times 3 \\
5 \times 6 \\
5 \times 6 \\
10 \times 14\end{array}$ \\
\hline \multirow{7}{*}{ Short-cycle agricultural crop } & Asteraceae & Helianthus annus & $1 \times 0,5$ \\
\hline & Curcubitaceae & Cucurbita maxima & $3 \times 3$ \\
\hline & Euphorbiaceae & Manihot esculenta & $1 \times 0,5$ \\
\hline & Fabaceae & Cajanus cajan & $1 \times 0,3$ \\
\hline & & Vigna unguiculata & $1 \times 0,5$ \\
\hline & Poaceae & Saccharum officinarum & $3 \times 3$ \\
\hline & & Zea mays & $1 \times 0,4$ \\
\hline
\end{tabular}

In April 2005, banana seedlings (Musa paradisiaca) were planted and fertilized with $3 \mathrm{~L}$ of tanned bovine manure and $100 \mathrm{~g}$ of potassium sulfate per planting hole, and pineapple seedlings (Ananas comosus) were planted and fertilized with $1 \mathrm{~L}$ of manure and $150 \mathrm{~g}$ of phosphorite per meter of furrow. Cassava (Manihot esculenta) seedlings were planted in unfertilized furrows, and tree seedlings (Albizia lebbeck, Schizolobium parahyba, Albizia saman, Pterogyne nitens, Acacia angustissima, Trichilia hirta, Senna macranthera, Piptadenia gonoacantha, Mimosa artemisiana, Colubrina glandulosa, Enterolobium contortisiliquum, Lonchocarpus guilleminianus, Morus nigra, Eugenia uniflora, Inga semialata, Syzygium cumini, Schinus terebinthifolius, Guazuma ulmifolia, Sparattosperma leucanthum, Bixa orellana, Syagrus romanzoffiana, and Chorisia speciosa) were planted in rows with cassava, without fertilization. Fabaceae seedlings were inoculated with nitrogen-fixing bacteria and arbuscular mycorrhizal fungi (Rhizophagus clarus and Gigaspora margarita). In December 2005, tree seeds were mixed with manure and broadcast in furrows or holes.

In January 2009, invasive grasses and spontaneous herbaceous plants were removed by hoeing and $50 \%$ of the canopy of trees with a diameter at breast height (DBH) greater than $4 \mathrm{~cm}$ was pruned to increase light penetration. Pruned biomass was minced and left on the soil. In April 2009, 200 Eritrin sp. cuttings and 25 Tectona grandis seedlings were planted. A year later, in January 2010, invasive grasses were removed by hoeing and 10$15 \%$ of the tree canopy ( $>4 \mathrm{~cm} \mathrm{DBH)}$ was pruned. Acacia angustissima individuals who were fallen, cracked, or infested with Struthanthus flexicaulis were removed. The system was enriched by planting 120 Euterpe edulis seedlings and 20 seedlings of each of the following tree species: Apuleia leiocarpa, Erythroxylum pulchrum, Cedrela fissilis, and Plathymenia foliosa. In April 2010, 60 Spondias sp. seedlings were planted. Between April 2008 and May 2010, the spontaneous occurrence of Eriotheca candolleana, Erythroxylum pulchrum, Anadenanthera sp., Mimosa bimucronata, and Eugenia brasiliensis was observed.

Soil sampling and soil fauna extraction were carried out in October 2016 (end of the dry season), when tree species were predominant in the area and there were no more short-cycle crops. Soil temperature and moisture content were determined in 0-5 cm depth soil samples. We determined soil fertility and texture analysis (clay, silt, and sand contents) in 0-5 and 5-10 cm depth samples.

We randomly installed ten $500 \mathrm{~mL}$ plastic pitfall traps $(17 \mathrm{~cm}$ height and $9.7 \mathrm{~cm}$ diameter $)$ in each site. Traps were buried in the ground with the rim at surface level, $10 \mathrm{~m}$ apart from each other, and were filled with about $100 \mathrm{~mL}$ of a $3 \%$ acetylsalicylic acid solution containing a few drops of detergent. Traps were left in the field for seven consecutive days. Then, the contents were sieved $(0.0053 \mathrm{~mm}$ mesh) and stored in $10 \mathrm{~mL}$ bottles containing $70 \%$ alcohol. Samples were transferred to a Petri dish with distilled water, and captured individuals were quantified and categorized into taxonomic groups (Class, Order, Family). Total abundance (individuals day ${ }^{-}$ ${ }^{1} \operatorname{trap}^{-1}$ ), relative abundance (\%), total richness (total number of taxa), mean richness (richness calculated among the replications), Pielou's evenness index, and Shannon's diversity index were estimated.

Soil moisture content $(0-5 \mathrm{~cm}$ depth) and soil temperature $(0-5 \mathrm{~cm}$ depth) were determined by the gravimetric method (DONAGEMA et al., 2011) and using a geothermometer, respectively, in 10 random sample points. At 10 random points, we determined the soil temperature $(0-5 \mathrm{~cm}$ deep) using a geothermometer and the soil moisture content (0-5 cm deep) by the gravimetric method (DONAGEMA et al., 2011). Soil pH in water, N, $\mathrm{P}, \mathrm{K}, \mathrm{Ca}, \mathrm{Mg}$, and $\mathrm{Na}$ contents, sum of bases, extractable acidity, and soil texture fractions (DONAGEMA et al., 2011) were determined in 10 samples of $0-5$ and 5-10 cm depth soil. Each sample was a composite of three samplings.

Soil physicochemical characteristics, total and relative abundance, and mean richness data were subjected to Levene's test of variance homogeneity. Means were compared by Student's t-test or Mann-Whitney nonparametric test. Pearson correlations were calculated between physicochemical soil attributes $(0-5 \mathrm{~cm}$ depth $)$ and mean richness, total abundance, and relative abundance of the 10 major taxonomic groups. The level of

FLORESTA, Curitiba, PR, v. 50, n. 1, p. 887 - 896, jan/mar 2020.

Camara, R. et.al.

ISSN eletrônico 1982-4688 
significance was set at $\mathrm{P}<0.05$ for all statistical analyses, and analyses were carried out using Statistica version 8.0. Soil physicochemical data were subjected to principal component analysis (PCA), followed by hierarchical clustering using Ward's criterion. Multivariate analyses were carried out using PAST version $2.17 \mathrm{c}$.

\section{RESULTS}

The analog agroforestry site had lower soil temperature and higher gravimetric soil moisture, total abundance, total richness, mean richness, evenness, and diversity of soil faunal groups than the pasture site (Table 2).

Table 2. Mean gravimetric soil moisture $\left(\mathrm{Ug}, \mathrm{g} \mathrm{g}^{-1}\right)$ and temperature $\left(\mathrm{T},{ }^{\circ} \mathrm{C}\right)$ at the $0-5 \mathrm{~cm}$ depth and total abundance $\left(\mathrm{Ab}\right.$, individuals trap $\left.{ }^{-1} \mathrm{day}^{-1}\right)$, mean richness $(\mathrm{Rm})$, total richness $(\mathrm{Rt})$, evenness $(\mathrm{U})$, and diversity $\left(\mathrm{H}^{\prime}\right)$ of the soil fauna community in analog agroforestry system and pasture sites in Seropédica, Rio de Janeiro, Brazil*.

Tabela 2. Valores médios de umidade gravimétrica $\left(\mathrm{Ug}, \mathrm{g} \mathrm{g}^{-1}\right)$ e temperatura do solo $\left(\mathrm{T},{ }^{\circ} \mathrm{C}\right)$ na camada de $0-5 \mathrm{~cm}$, e de abundância total ( $\mathrm{Ab}$, ind ${ }^{-1}$ armadilha $\left.^{-1} \mathrm{dia}^{-1}\right)$, riqueza média $(\mathrm{Rm})$, riqueza total (Rt), uniformidade (U) e diversidade ( $\left.\mathrm{H}^{\prime}\right)$ da comunidade da fauna do solo, nas áreas de sistema agroflorestal regenerativo análogo e pastagem, Seropédica, RJ, Brasil*.

\begin{tabular}{cccccccc}
\hline Site & $\mathrm{Ug}$ & $\mathrm{T}$ & $\mathrm{Ab}$ & $\mathrm{Rm}$ & $\mathrm{Rt}$ & $\mathrm{U}$ & $\mathrm{H}^{\prime}$ \\
\hline Analog agroforestry system & $9.98 \mathrm{~A}$ & $24.1 \mathrm{~B}$ & $74.33 \mathrm{~A}$ & $15 \mathrm{~A}$ & 24 & 0.76 & 3.36 \\
Pasture & $4.89 \mathrm{~B}$ & $27.4 \mathrm{~A}$ & $48.40 \mathrm{~B}$ & $13 \mathrm{~B}$ & 20 & 0.64 & 2.75
\end{tabular}

* Values are the mean of 10 replications. Means within a column followed by different letters differ significantly (Student's t-test or MannWhitney non-parametric test, $\mathrm{P}<0.05)$.

The results indicated that the soil fauna community in the analog agroforestry site was markedly different from that found in the pasture site. In the analog agroforest system, most individuals (63\%) belonged to four taxa: Diptera (22\%), a group that is not edaphic and has no well-known function in the soil fauna community; Entomobryomorpha (17\%), a group of microphagous organisms; and Formicidae (13\%) and Coleoptera (12\%), both represented by saprophages and/or predators (Figure 1). The soil fauna community in the pasture site was represented $(73 \%)$ by three major taxonomic groups: Entomobryomorpha (31\%), followed by Diplopoda (22\%, includes mainly saprophages) and Formicidae (21\%).

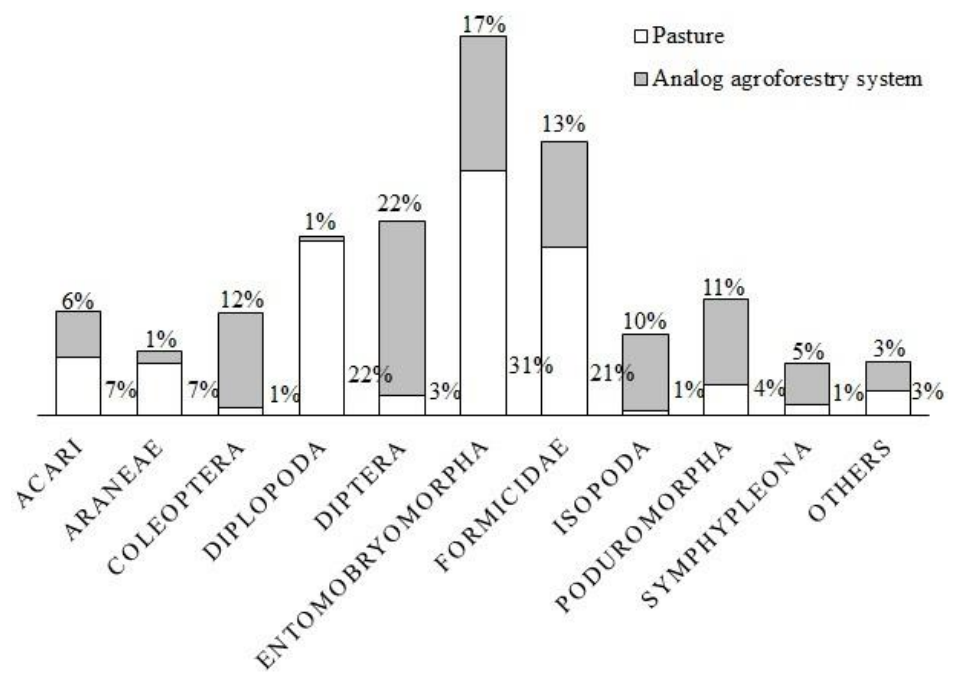

Figure. 1. Relative abundance (\%) of soil faunal groups in analog agroforestry system and pasture sites in Seropédica, Rio de Janeiro, Brazil.

Figura 1. Abundância relativa (\%)de grupos taxonômicos nas áreas de sistema agroflorestal regenerativo análogo e pastagem, Seropédica, RJ, Brasil.

Five taxonomic groups presented higher relative abundance in the analog agroforestry site: Isopoda (14\%, represented by saprophages), Coleoptera (12\%), Diptera (8\%), Symphypleona (4\%, microphages), and 
Poduromorpha (3\%, microphages) (Figure 1). In contrast, Diplopoda (38\%), Araneae (5\%, represented by predators), Entomobryomorpha (2\%), and Formicidae (2\%) had higher relative abundance in the pasture site.

Coleoptera, Diptera, Hymenoptera (predators), Isopoda, Lepidoptera (non-edaphic organisms with no known function in the soil community), Poduromorpha, and Symphypleona were more abundant in agroforest soil (Table 3). Only Diplopoda was more abundant in pasture soil. The total abundances of other taxonomic groups did differ significantly between sites.

Table 3. Mean and standard error (SE) of the total abundance (individuals trap ${ }^{-1}$ day $^{-1}$ ) of soil faunal groups in analog agroforestry system and pasture sites in Seropédica, Rio de Janeiro, Brazil*.

Tabela 3. Valores médios e erro-padrão (SE) da abundância (indivíduos armadilha ${ }^{-1}$ dia $^{-1}$ ) dos grupos taxonômicos da comunidade da fauna do solo, nas áreas de sistema agroflorestal regenerativo análogo e pastagem, Seropédica, RJ, Brasil*.

\begin{tabular}{lcccc}
\hline \multicolumn{1}{c}{ Taxonomic group } & \multicolumn{2}{c}{ Analog agroforestry system } & \multicolumn{2}{c}{ Pasture } \\
\hline Acari & mean & SE & mean & SE \\
Araneae & $4.37 \mathrm{~A}$ & 0.65 & $3.56 \mathrm{~A}$ & 0.44 \\
Archaeognatha & $1.10 \mathrm{~A}$ & 0.18 & $3.20 \mathrm{~A}$ & 1.19 \\
Auchenorrhyncha & $0.00 \mathrm{~A}$ & 0.00 & $0.01 \mathrm{~A}$ & 0.01 \\
Blattodea & $0.51 \mathrm{~A}$ & 0.14 & $0.67 \mathrm{~A}$ & 0.09 \\
Coleoptera & $0.13 \mathrm{~A}$ & 0.06 & $0.17 \mathrm{~A}$ & 0.05 \\
Diplopoda & $9.17 \mathrm{~A}$ & 1.77 & $0.47 \mathrm{~B}$ & 0.07 \\
Diptera & $0.44 \mathrm{~B}$ & 0.20 & $10.51 \mathrm{~A}$ & 1.60 \\
Entomobryomorpha & $1.73 \mathrm{~A}$ & 2.71 & $1.29 \mathrm{~B}$ & 0.20 \\
Formicidae & $13.07 \mathrm{~A}$ & 1.85 & $14.77 \mathrm{~A}$ & 2.28 \\
Gastropoda & $10.13 \mathrm{~A}$ & 2.25 & $10.21 \mathrm{~A}$ & 3.72 \\
Heteroptera & $0.01 \mathrm{~A}$ & 0.01 & $0.00 \mathrm{~A}$ & 0.00 \\
Hymenoptera & $0.11 \mathrm{~A}$ & 0.10 & $0.01 \mathrm{~A}$ & 0.01 \\
Isopoda & $0.57 \mathrm{~A}$ & 0.11 & $0.13 \mathrm{~B}$ & 0.08 \\
Isoptera & $7.43 \mathrm{~A}$ & 2.09 & $0.33 \mathrm{~B}$ & 0.13 \\
Larva de Coleoptera & $0.06 \mathrm{~A}$ & 0.03 & $0.01 \mathrm{~A}$ & 0.01 \\
Larva de Diptera & $0.11 \mathrm{~A}$ & 0.08 & $0.00 \mathrm{~A}$ & 0.00 \\
Larva de Lepidoptera & $0.01 \mathrm{~A}$ & 0.01 & $0.00 \mathrm{~A}$ & 0.00 \\
Larva de Neuroptera & $0.09 \mathrm{~A}$ & 0.04 & $0.00 \mathrm{~A}$ & 0.00 \\
Lepidoptera & $0.03 \mathrm{~A}$ & 0.02 & $0.00 \mathrm{~A}$ & 0.00 \\
Orthoptera & $0.09 \mathrm{~A}$ & 0.02 & $0.00 \mathrm{~B}$ & 0.00 \\
Phasmatodea & $0.50 \mathrm{~A}$ & 0.13 & $0.26 \mathrm{~A}$ & 0.06 \\
Poduromorpha & $0.00 \mathrm{~A}$ & 0.00 & $0.01 \mathrm{~A}$ & 0.01 \\
Pseudoscorpionida & $8.26 \mathrm{~A}$ & 1.85 & $1.86 \mathrm{~B}$ & 0.52 \\
Psocoptera & $0.01 \mathrm{~A}$ & 0.01 & $0.00 \mathrm{~A}$ & 0.00 \\
Symphypleona & $0.41 \mathrm{~A}$ & 0.15 & $0.17 \mathrm{~A}$ & 0.06 \\
Thysanoptera & $4.04 \mathrm{~A}$ & 0.81 & $0.64 \mathrm{~B}$ & 0.16 \\
\hline & $0.04 \mathrm{~A}$ & 0.02 & $0.10 \mathrm{~A}$ & 0.06 \\
\hline
\end{tabular}

* Values are the mean of 10 replications. Means within a row followed by different letters differ significantly (Student's t-test or Mann-Whitney non-parametric test, $\mathrm{P}<0.05)$.

Seven taxonomic groups, namely, Gastropoda (saprophages), Pseudoscorpionida (predators), and Lepidoptera and larvae of Coleoptera, Diptera, Lepidoptera, and Neuroptera (saprophages and/or predators), were only captured in the analog agroforestry site (Table 3). On the other hand, only two taxonomic groups, namely, Archaeognatha (saprophages) and Phasmatodea (herbivores), were exclusive to the pasture site.

Soil sand content, $\mathrm{pH}$, calcium, magnesium, and sum of exchangeable bases were significantly higher in the agroforestry site, both at the 0-5 and 5-10 cm depths (Table 4). Pasture soil had higher available phosphorus, exchangeable potassium, extractable acidity, and total organic carbon content in both depth layers and higher silt content in the $5-10 \mathrm{~cm}$ layer than agroforest soil.

Table 4. Mean values of contents of sand, clay, silt, total organic carbon (TOC), and nitrogen (N; $\left.\mathrm{g} \mathrm{kg}^{-1}\right)$, available phosphorus $\left(\mathrm{P} ; \mathrm{mg} \mathrm{kg}^{-3}\right), \mathrm{pH}$ (in water), calcium $(\mathrm{Ca})$, magnesium $(\mathrm{Mg})$, potassium $(\mathrm{K})$, sodium $(\mathrm{Na})$, sum of bases $(\mathrm{SB})$, and extractable acidity $\left(\mathrm{H}+\mathrm{Al} ; \mathrm{cmol}_{\mathrm{c}} \mathrm{kg}^{-1}\right)$, folowed by standard deviation in parenthesis, of soils sampled at 0-5 and 5-10 cm depth in analog agroforestry system and pasture sites in Seropédica, Rio de Janeiro, Brazil*.

FLORESTA, Curitiba, PR, v. 50, n. 1, p. 887 - 896, jan/mar 2020

Camara, R. et.al.

ISSN eletrônico 1982-4688

DOI: $10.5380 /$ rf.v50 i1.57476 
Tabela 4. Valores médios de conteúdo $\left(\mathrm{g} \mathrm{kg}^{-1}\right)$ de areia, argila, silte, carbono orgânico total (TOC) e nitrogênio $\left(\mathrm{N} ; \mathrm{g} \mathrm{kg}^{-1}\right)$, fósforo disponível ( $\left.\mathrm{P} ; \mathrm{mg} \mathrm{kg}^{-1}\right)$, $\mathrm{pH}$ (em água), cálcio $(\mathrm{Ca})$, magnésio $(\mathrm{Mg})$, potássio $(\mathrm{K})$, sódio $(\mathrm{Na})$, soma de bases $(\mathrm{SB})$ e acidez extraível $\left(\mathrm{H}+\mathrm{Al} ; \mathrm{cmol}_{\mathrm{c}} \mathrm{kg}^{-1}\right)$, seguidos do desvio padrão entre parênteses, nas camadas de 0-5 e 5-10 cm, nas áreas de sistema agroflorestal regenerativo análogo e pastagem, Seropédica, RJ, Brasil*.

\begin{tabular}{lcccc}
\hline Soil attributes & \multicolumn{2}{c}{ Analog agroforestry system } & \multicolumn{2}{c}{ Pasture } \\
\cline { 2 - 5 } & $0-5 \mathrm{~cm}$ & $5-10 \mathrm{~cm}$ & $0-5 \mathrm{~cm}$ & $5-10 \mathrm{~cm}$ \\
\hline Sand & $700.80(45.33) \mathrm{A}$ & $718.90(51.24) \mathrm{A}$ & $63.57(14.38) \mathrm{B}$ & $614.00(120.90) \mathrm{B}$ \\
Clay & $181.60(52.09) \mathrm{A}$ & $191.50(40.43) \mathrm{A}$ & $241.40(86.25) \mathrm{A}$ & $219.10(81.41) \mathrm{A}$ \\
Silt & $117.60(45.54) \mathrm{A}$ & $89.60(30.92) \mathrm{B}$ & $122.90(69.73) \mathrm{A}$ & $166.90(87.11) \mathrm{A}$ \\
TOC & $26.02(3.68) \mathrm{B}$ & $23.83(3.37) \mathrm{B}$ & $31.02(4.08) \mathrm{A}$ & $24.86(3.79) \mathrm{A}$ \\
$\mathrm{N}$ & $0.38(0.06) \mathrm{A}$ & $0.36(0.05) \mathrm{A}$ & $0.42(0.06) \mathrm{A}$ & $0.36(0.04) \mathrm{A}$ \\
$\mathrm{P}$ & $6.06(1.46) \mathrm{B}$ & $5.43(2.07) \mathrm{B}$ & $17.12(8.95) \mathrm{A}$ & $13.62(6.62) \mathrm{A}$ \\
$\mathrm{pH}$ & $5.29(0.12) \mathrm{B}$ & $5.13(0.12) \mathrm{B}$ & $4.25(0.12) \mathrm{A}$ & $4.08(0.15) \mathrm{A}$ \\
$\mathrm{Ca}$ & $2.10(0.32) \mathrm{A}$ & $1.85(0.24) \mathrm{A}$ & $1.74(0.34) \mathrm{B}$ & $0.97(0.27) \mathrm{B}$ \\
$\mathrm{Mg}$ & $2.35(0.39) \mathrm{A}$ & $1.76(0.24) \mathrm{A}$ & $1.77(0.30) \mathrm{B}$ & $1.41(0.32) \mathrm{B}$ \\
$\mathrm{K}$ & $0.07(0.02) \mathrm{B}$ & $0.04(0.02) \mathrm{B}$ & $0.10(0.02) \mathrm{A}$ & $0.07(0.02) \mathrm{A}$ \\
$\mathrm{Na}$ & $0.02(0.00) \mathrm{A}$ & $0.02(0.00) \mathrm{A}$ & $0.02(0.00) \mathrm{A}$ & $0.02(0.00) \mathrm{A}$ \\
$\mathrm{SB}$ & $4.53(0.43) \mathrm{A}$ & $3.67(0.31) \mathrm{A}$ & $3.63(0.53) \mathrm{B}$ & $2.46(0.48) \mathrm{B}$ \\
$\mathrm{H}+\mathrm{Al}$ & $4.74(0.67) \mathrm{B}$ & $4.60(0.76) \mathrm{B}$ & $9.29(1.35) \mathrm{A}$ & $8.63(0.85) \mathrm{A}$ \\
\hline
\end{tabular}

$*$ Values are the mean and standard deviation (in parentheses) of 10 replications. Means within a row followed by different letters differ significantly (Student's t-test or Mann-Whitney non-parametric test, $\mathrm{P}<0.05$ ).

PCA extracted two principal components (PC1 and PC2), which together accounted for about $94 \%$ of the total variance in the dataset. PC1 explained $64.35 \%$ of the variance and PC2 $29.40 \%$ (Figure $2 \mathrm{a}$ ). The two experimental sites and different soil layers were clearly separated in the PCA biplot. The pasture site was located on the positive side of the PC1 axis, whereas the analog agroforestry system site was located on the negative side. Soil layers appear on different sides of the PC2 axis, the $0-5 \mathrm{~cm}$ layer in the positive region and the $5-10 \mathrm{~cm}$ layer in the negative region.

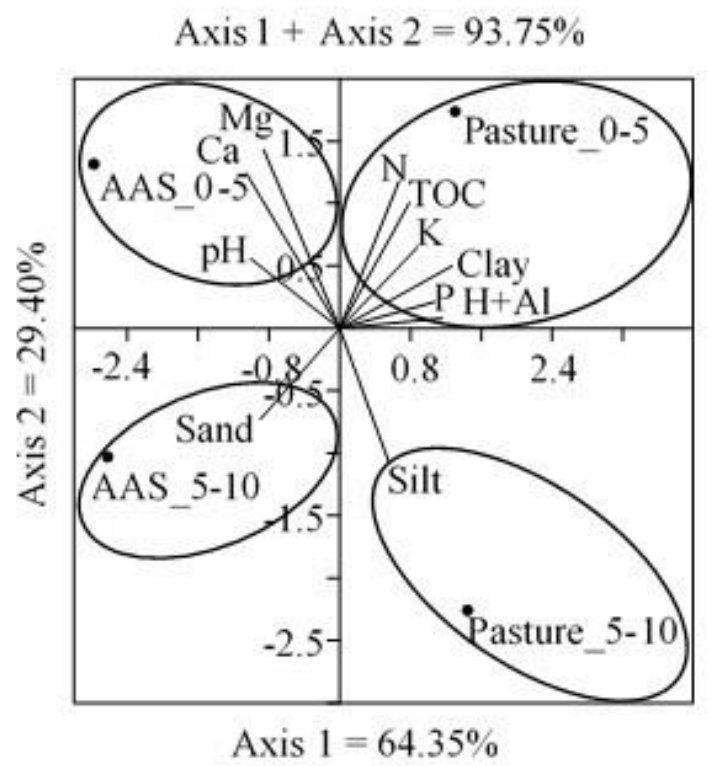

(a)

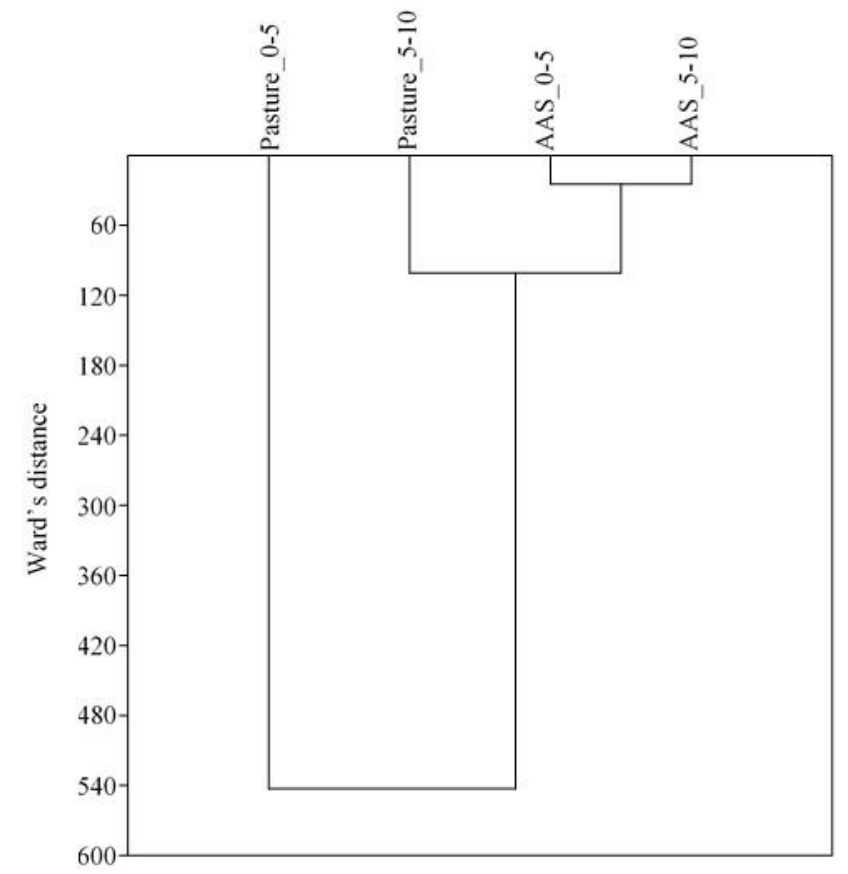

(b)

Figure 2. Principal components analysis (a) and hierarchical dendrogram based on Ward's method (b) for soil chemical attributes at the 0-5 and 5-10 cm depths, in analog agroforestry system (AAS) and pasture sites in Seropédica, Rio de Janeiro, Brazil. 
Figura 2. Análise de componentes principais (a) e dendrograma de agrupamento hierárquico (b) para os valores médios dos atributos químicos do solo $(0-5$ e 5-10 cm), nas áreas de sistema agroflorestal regenerativo análogo (AAS) e pastagem, Seropédica, RJ, Brasil.

The $0-5 \mathrm{~cm}$ soil layer was associated with more chemical soil parameters than the $5-10 \mathrm{~cm}$ layer for both sites (Figure 2a). In the agroforestry site, the $0-5 \mathrm{~cm}$ soil layer was associated with higher $\mathrm{Ca}, \mathrm{Mg}$, and $\mathrm{pH}$, and the $5-10 \mathrm{~cm}$ soil layer with higher sand content. In the pasture site, the $0-5 \mathrm{~cm}$ soil layer was associated with higher $\mathrm{N}, \mathrm{P}, \mathrm{K}, \mathrm{TOC}$, and extractable acidity, and the $5-10 \mathrm{~cm}$ layer was associated with higher silt content.

Hierarchical cluster analysis identified two large groups (Figure 2b). The first was formed by agroforest soil samples collected from the 0-5 and 5-10 cm layers, which were within 20 distance units of each other, and pasture soil samples collected at the $5-10 \mathrm{~cm}$ depth, located about 100 units away. The second group contained only pasture soil samples collected from the $0-5 \mathrm{~cm}$ layer. The two groups were about 540 distance units apart. These results indicate that there is a large dissimilarity between the two experimental sites, due to soil chemical attributes in the $0-5 \mathrm{~cm}$ layer.

Soil fauna abundance and mean richness showed a significant positive correlation with soil sand content, $\mathrm{pH}$, and magnesium and a significant negative correlation with soil temperature, potassium, and extractable acidity at the $0-5 \mathrm{~cm}$ depth (Tables 5 and 6).

Table 5. Pearson's correlation between total abundance $(\mathrm{Ab})$, mean richness $(\mathrm{Rm})$, and relative abundance of the 10 most abundant taxonomic groups of the soil fauna community and gravimetric soil moisture $(\mathrm{Ug})$, temperature (T), contents of sand, clay, silt, total organic carbon (TOC), nitrogen (N), and available phosphorus (P) at the $0-5 \mathrm{~cm}$ depth in analog agroforestry and pasture sites in Seropédica, Rio de Janeiro, Brazil.

Tabela 5. Valores de coeficiente de correlação de Pearson entre a abundância total (Ab), riqueza média (Rm) e a abundância dos 10 grupos taxonômicos mais representativos da comunidade da fauna do solo, e a umidade gravimétrica (Ug), temperatura do solo (T), conteúdos de areia, argila, silte, carbono orgânico total (TOC), nitrogênio e fósforo disponível na camada de 0-5 cm, nas áreas de sistema agroflorestal regenerativo análogo e pastagem, Seropédica, RJ, Brasil.

\begin{tabular}{lcccccccc}
\hline Attribute & $\mathrm{Ug}$ & $\mathrm{T}$ & Sand & Clay & Silt & TOC & $\mathrm{N}$ & $\mathrm{P}$ \\
\hline $\mathrm{Ab}$ & 0.1395 & $-0.4457^{*}$ & $0.6077^{*}$ & -0.3668 & -0.3379 & -0.4177 & -0.3071 & -0.2229 \\
$\mathrm{Rm}$ & 0.4255 & $-0.7082^{*}$ & $0.7396^{*}$ & -0.3734 & -0.1694 & -0.3461 & -0.2363 & $-0.4497^{*}$ \\
$\mathrm{Aca}$ & 0.0822 & -0.2689 & 0.2536 & -0.1026 & -0.1608 & -0.4341 & -0.0701 & -0.1452 \\
$\mathrm{Ara}$ & -0.3645 & 0.3389 & -0.3720 & 0.2054 & -0.1572 & 0.3918 & 0.0587 & 0.1749 \\
$\mathrm{Cole}$ & 0.3161 & $-0.6751^{*}$ & $0.7875^{*}$ & -0.3826 & -0.1691 & -0.3239 & -0.1959 & $-0.5349^{*}$ \\
$\mathrm{Dipl}$ & $-0.6962^{*}$ & $0.8925^{*}$ & $-0.8205^{*}$ & 0.3467 & -0.0733 & 0.3900 & $0.4598^{*}$ & 0.6484 \\
$\mathrm{Dipt}$ & $0.5491^{*}$ & $-0.7482^{*}$ & $0.8160^{*}$ & $-0.4630^{*}$ & 0.0475 & -0.2949 & -0.3825 & $-0.5056^{*}$ \\
Ento & $-0.4666^{*}$ & 0.2659 & -0.1023 & -0.0200 & $-0.6775^{*}$ & 0.0730 & -0.1514 & 0.4129 \\
Formi & -0.0572 & 0.0061 & -0.0064 & 0.0040 & -0.2117 & -0.2885 & -0.3422 & 0.1741 \\
Iso & 0.4209 & $-0.5117^{*}$ & $0.6187^{*}$ & -0.2023 & -0.0805 & -0.4308 & 0.1760 & -0.3990 \\
Podu & 0.2530 & $-0.5499^{*}$ & $0.6544^{*}$ & $-0.5557^{*}$ & 0.0153 & $-0.5187^{*}$ & -0.4038 & -0.4148 \\
Sym & 0.3569 & $-0.6109^{*}$ & $0.6974^{*}$ & -0.2026 & -0.0911 & -0.4179 & -0.1504 & $-0.5319^{*}$ \\
\hline
\end{tabular}

* Significant (P < 0.05). Aca, Acari; Ara, Araneae; Cole, Coleoptera; Dipl, Diplopoda; Dipt, Diptera; Ento, Entomobryomorpha; Formi, Formicidae; Iso, Isopoda; Podu, Poduromorpha; Sym, Symphypleona.

At least half of the 10 most abundant taxonomic groups presented a significant positive correlation with soil sand content and $\mathrm{pH}$, and presented a significant negative correlation with soil temperature and extractable acidity at the 0-5 cm depth (Tables 5 and 6). Soil sodium levels showed no significant correlation with fauna community composition.

Table 6. Pearson's correlation between total abundance (Ab), mean richness $(\mathrm{Rm})$, and relative abundance of the 10 most abundant taxonomic groups of the soil fauna community and soil $\mathrm{pH}$, calcium $(\mathrm{Ca})$, magnesium $(\mathrm{Mg})$, potassium $(\mathrm{K})$, sodium $(\mathrm{Na})$, sum of bases $(\mathrm{SB})$, and extractable acidity $(\mathrm{H}+\mathrm{Al})$ in the $0-5 \mathrm{~cm}$ layer in analog agroforestry system and pasture sites in Seropédica, Rio de Janeiro, Brazil.

Tabela 6. Valores de coeficiente de correlação de Pearson entre a abundância total (Ab), riqueza média (Rm) e a abundância dos 10 grupos taxonômicos mais representativos da comunidade da fauna do solo, e $\mathrm{pH}$, cálcio $(\mathrm{Ca})$, magnésio $(\mathrm{Mg})$, potássio $(\mathrm{K})$, sódio $(\mathrm{Na})$, soma de bases $(\mathrm{SB})$ e acidez extraível $(\mathrm{H}+\mathrm{Al})$

FLORESTA, Curitiba, PR, v. 50, n. 1, p. 887 - 896, jan/mar 2020.

Camara, R. et.al.

ISSN eletrônico 1982-4688

DOI: $10.5380 /$ rf.v50 i1.57476 
na camada de 0-5 cm, nas áreas de sistema agroflorestal regenerativo análogo e pastagem, Seropédica, RJ, Brasil.

\begin{tabular}{lccccccc}
\hline Attribute & $\mathrm{pH}$ & $\mathrm{Ca}$ & $\mathrm{Mg}$ & $\mathrm{K}$ & $\mathrm{Na}$ & $\mathrm{SB}$ & $\mathrm{H}+\mathrm{Al}$ \\
\hline $\mathrm{Ab}$ & $0.5700^{*}$ & 0,0550 & $0,6030^{*}$ & $-0,5267^{*}$ & $-0,3312$ & 0,4200 & $-0,5893^{*}$ \\
$\mathrm{Rm}$ & $0.7134^{*}$ & 0,0677 & $0,5084^{*}$ & $-0,5334^{*}$ & $-0,2651$ & 0,3628 & $-0,7176^{*}$ \\
$\mathrm{Aca}$ & 0.2047 & -0.1206 & 0.2517 & $-0.4749^{*}$ & -0.0837 & 0.0846 & -0.2599 \\
$\mathrm{Ara}$ & -0.3769 & $-0.4964^{*}$ & -0.1109 & 0.1043 & 0.1159 & -0.3510 & 0.4157 \\
$\mathrm{Cole}$ & $0.7834^{*}$ & $0.4643^{*}$ & $0.6338^{*}$ & $-0.5225^{*}$ & -0.1578 & $0.6728^{*}$ & $-0.7025^{*}$ \\
$\mathrm{Dipl}$ & $-0.8243^{*}$ & -0.4346 & -0.4268 & 0.5008 & 0.1952 & $-0.5156^{*}$ & 0.8423 \\
$\mathrm{Dipt}$ & 0.7712 & 0.3615 & 0.6104 & -0.2594 & -0.2181 & $0.6089^{*}$ & $-0.7329^{*}$ \\
Ento & -0.0971 & -0.1207 & 0.0954 & -0.1711 & -0.1925 & -0.0106 & 0.1291 \\
Formi & -0.0280 & -0.1946 & 0.0093 & -0.2387 & -0.2746 & -0.1140 & -0.1586 \\
Iso & $0.6427^{*}$ & 0.1633 & $0.4813^{*}$ & $-0.5464^{*}$ & -0.2041 & 0.3980 & $-0.5866^{*}$ \\
Podu & $0.5852^{*}$ & -0.0006 & $0.5137^{*}$ & -0.4249 & -0.2730 & 0.3321 & $-0.6787^{*}$ \\
Sym & $0.7308^{*}$ & 0.3541 & $0.6547^{*}$ & $-0.6080^{*}$ & -0.0832 & $0.6219^{*}$ & $-0.6584^{*}$ \\
\hline
\end{tabular}

* Significant (P < 0.05). Aca, Acari; Ara, Araneae; Cole, Coleoptera; Dipl, Diplopoda; Dipt, Diptera; Ento, Entomobryomorpha; Formi, Formicidae; Iso, Isopoda; Podu, Poduromorpha; Sym, Symphypleona.

Coleoptera, Isopoda, Poduromorpha, Symphypleona, and Diptera presented a significant positive correlation with soil sand content, $\mathrm{pH}$, magnesium, and sum of bases. On the other hand, these taxonomic groups presented a significant negative correlation with soil temperature and $\mathrm{H}+\mathrm{Al}$ (Tables 5 and 6). There was no clear correlation between the presence of Acari, Araneae, Diplopoda, and Entomobryomorpha and soil physical and chemical attributes. Formicidae was the only group that did not show a significant correlation with the soil attributes.

\section{DISCUSSION}

Total and relative abundance, richness, evenness, and diversity of the soil fauna community were higher in the analog agroforestry system site. This site also had a larger number of taxonomic groups (Coleoptera, Diptera, Gastropoda, Hymenoptera, Isopoda, Lepidoptera, Poduromorpha, Symphypleona, Pseudoscorpionida, and Lepidoptera adults and Coleoptera, Diptera, Lepidoptera, and Neuroptera larvae), probably because of its higher soil moisture content and lower soil temperature compared with the pasture site, where fewer taxonomic groups were observed (Araneae, Archaeognatha, Diplopoda, Entomobryomorpha, Formicidae, and Phasmatodea).

Milder soil microclimatic conditions, which favor the diversity and complexity of the soil fauna community (CAMARA et al., 2012; POMPEO et al., 2016), occurred in agroforest soil, even though the soil had a higher content of sand than pasture soil. It seems that microclimatic conditions were not greatly influenced by differences in soil type (Red Yellow Acrisol in the pasture site and haplic Planosol in the agroforestry site). Moisture retention is generally lower in soils with high sand contents (ANDRADE; STONE, 2011). Therefore, leaf litter was the key factor for the good soil microclimatic conditions in the analog agroforestry site. A similar result was observed in an agroforestry site in Cuba: total abundance and richness of the soil fauna community were higher than that of a pasture site because of the soil cover provided by plant material (CABRERA-DÁVILA et al., 2017). The abundant and heterogeneous litter observed in the analog agroforestry site may also have provided a greater variety of food resources for the soil fauna community (CAMARA et al., 2012; POMPEO et al., 2016).

The higher calcium and magnesium levels observed in analog agroforest system soil were probably due to plant litter, as this site was not fertilized with agricultural lime. Phosphorus and potassium contents were higher in pasture soil because of mineral and organic (cattle urine and feces) fertilization. Higher TOC levels were observed in pasture soil as a consequence of the constant deposition of organic material (QASEM, 1992). In a study carried out in Rio Doce Valley, Minas Gerais, Brazil, agroforest soil had higher pH, magnesium content, and sum of bases, whereas pasture soil had higher TOC content (FÁVERO et al., 2008).

Soil chemical attributes were associated with the $0-5 \mathrm{~cm}$ soil layer in both areas. Contact with plant debris and the high activity of decomposers in this layer contribute to soil fertility, which usually decreases with depth, regardless of soil type (CEZAR et al., 2015; MARTINS et al., 2015).

There was a significant and positive correlation of total abundance and richness with sand content, $\mathrm{pH}$, and magnesium levels. The soil fauna community, therefore, is positively influenced by soil management practices that lead to increased soil $\mathrm{pH}$ and magnesium contents (LOURENTE et al., 2007; BARETTA et al., 2014). High soil $\mathrm{pH}$ is a reflection of the availability of specific ions in the soil solution, which interfere with the structure of the soil fauna community (POMPEO et al., 2016). Soils with high sand content have increased aeration, facilitating the movement of soil fauna. 
Total abundance and richness presented a significant and negative correlation with soil temperature, potassium, and extractable acidity. Temperature is one of the main factors affecting the metabolism of soil fauna and, consequently, their spatial activity and distribution (POMPEO et al., 2016). Richness and abundance are negatively affected by high extractable acidity (BARETTA et al., 2014).

Lourente et al. (2007), analyzing soil fauna in Maracaju, Mato Grosso do Sul, Brazil, found that Formicidae abundance was not significantly correlated with physicochemical parameters of soils under different types of management, such as conventional farming, no-till farming, pasture, eucalyptus and native forest, and silvopasture.

\section{CONCLUSIONS}

The analyzes carried out allow us to conclude that:

- Some physical, chemical, and biological soil attributes can be used as indicators of soil quality in analog agroforestry system and pasture sites.

- The total abundance, total richness, mean richness, evenness, and diversity of the soil fauna community, as well as gravimetric soil moisture, sand content, $\mathrm{pH}$, calcium, magnesium, and sum of bases were higher in the soil under analog agroforestry system when compared to the pasture site.

- In soil under pasture, we observed higher values of temperature, extractable acidity, available phosphorus, exchangeable potassium, and TOC content in relation to the analog agroforestry system site.

- The $0-5 \mathrm{~cm}$ soil layer was associated with more chemical soil attributes than the 5-10 $\mathrm{cm}$ layer for both experimental sites.

- Adults of Coleoptera, Diptera, Gastropoda, Hymenoptera, Isopoda, Lepidoptera, Poduromorpha, Symphypleona, Pseudoscorpionida, and Lepidoptera and larvae of Coleoptera, Diptera, Lepidoptera, and Neuroptera were most abundant in soil under analog agroforest system.

- Araneae, Archaeognatha, Diplopoda, Entomobryomorpha, Formicidae, and Phasmatodea were predominantly found in soil under pasture.

- The total abundance and mean richness of the soil fauna groups presented a significant positive correlation with soil sand content, $\mathrm{pH}$, and magnesium content and a significant negative correlation with soil temperature, potassium content, and extractable acidity.

\section{ACKNOWLEDGEMENTS}

The authors thank Dra. Eliane Maria Ribeiro da Silva from EMBRAPA Agrobiology for her kind permission to collect soil samples from the experimental sites.

\section{REFERÊNCIAS}

AlvareS, C. A.; STAPE, J. L.; SENTElHAS, P. C.; GONÇAlVES, J. L. M.; SPAROVEK, G. Köppen's climate classification map for Brazil. Meteorologische Zeitschrift, Stuttgart, v. 22, n. 6, p. 711-728, 2013.

ANDRADE, R. S.; STONE, L. F. Estimativa da umidade na capacidade de campo em solos sob Cerrado. Revista Brasileira de Engenharia Agrícola e Ambiental, Campina Grande, v. 15, n. 2, p. 111-116, 2011.

BARETTA, D.; BARTZ, M. L. C.; FACHINI, I.; ANSELMI, R.; ZORTÉA, T.; BARETTA, C. R. D. M. Soil fauna and its relation with environmental variables in soil management systems. Revista Ciência Agronômica, Fortaleza, v. 45, n. 5, p. 871 - 879, 2014.

CABRERA-DÁVILA, G. C.; SOCARRÁS-RIVERO, A. A.; HERNÁNDEZ-VIGOA, G.; LEÓN-LIMA, D. P.; MENÉNDEZ-RIVERO, Y. I.; SÁNCHEZ-RONDÓN, J. A. Evaluación de la macrofauna como indicador del estado de salud en siete sistemas de uso de la tierra, en Cuba. Pastos y Forrajes, Matanzas, v. 40, n. 2 , p. 118 $126,2017$.

CAMARA, R.; CORREIA, M. E. F.; VILLELA, D. M. Effects of eucalyptus plantations on soil arthropod communities in a Brazilian Atlantic Forest conservation. Bioscience Journal, Uberlândia, v. 28, n. 3, p. 445 - 455 , 2012.

FLORESTA, Curitiba, PR, v. 50, n. 1, p. 887 - 896, jan/mar 2020.

Camara, R. et.al.

ISSN eletrônico 1982-4688

DOI: 10.5380/rf.v50 i1.57476 
CARVALHO, D. F.; SILVA, D. G.; SOUZA, A. P.; GOMES, D. P.; ROCHA, H. S. Coeficientes da equação de Angström-Prescott e sua influência na evapotranspiração de referência em Seropédica, RJ. Revista Brasileira de Engenharia Agrícola, Campina Grande, v. 15, n. 8, p. 108 - 116, 2011.

CEZAR, R. M.; VEZZANI, F. M.; SCHWIDERKE, D. K.; GAIAD, S.; BROWN, G. G.; SEOANE, C. E. S.; FROUFE, L. C. M. Soil biological properties in multistrata sucessional agroforestry systems and in natural regeneration. Agroforestry Systems, Netherlands, v. 89, n. 6, p. 1035 - 1047, 2015.

CORRÊA NETO, T. A.; ANJOS, L. H. C.; PEREIRA, M. G. P.; JACCOUD, C. F. S. Aporte de serapilheira em plantios de eucalipto em função da qualidade do sítio. Pesquisa Florestal Brasileira, Colombo, v. 34, n. 80, p.399 - 406, 2014.

DIAS, P. F.; SOUTO, S. M.; CORREIA, M. E. F.; ROCHA, G. P.; MOREIRA, J. F.; RODRIGUES, K. M.; FRANCO, A. A. Árvores fixadoras de nitrogênio e macrofauna do solo em pastagem de híbrido de Digitaria. Pesquisa Agropecuária Brasileira, Brasília, v. 41, n. 6, p. 1015 - 1021, 2006.

DONAGEMA, G.K.; CAMPOS, D.V.B. de; CALDERANO, S.B.; TEIXEIRA, W.G.; VIANA, J.H.M. (Org.). Manual de métodos de análise de solos. 2.ed. rev. Rio de Janeiro: Embrapa Solos, 2011, 230p.

DUARTE, E. M. G.; CARDOSO, I. M.; STIJNEN, T.; MENDONÇA, M. A. F. C.; COELHO, M. S.; CANTARUTTI, R. B.; KUYPER, T. W.; VILLANI, E. M. A.; MENDONÇA, E. S. Decomposition and nutrient release in leaves of Atlantic Rainforest tree species used in agroforestry systems. Agroforestry Systems, Netherlands, v. 87, n. 4, p. 835 - 847, 2013.

FÁVERO, C.; LOVO, I. C.; MENDONÇA, E. S. Recuperação de área degradada com sistema agroflorestal no Vale do Rio Doce, Minas Gerais. Revista Árvore, Viçosa, v. 32, n. 5, p. 861 - 868, 2008.

JOSE, S. Agroforestry for conserving and enhancing biodiversity. Agroforestry Systems, Netherlands, v. 85, n. 1, p. 1 - 8, 2012.

LOURENTE, E. R. P.; SILVA, R. F.; SILVA, D. A.; MARCHETTI, M. E.; MERCANTE, F. M. Macrofauna edáfica e sua interação com atributos químicos e físicos do solo sob diferentes sistemas de manejo. Acta Scientiarum Agronomy, Maringá, v.29, n.1, p.17-22, 2007.

MARTINS, E. M.; SILVA, E. R.; CAMPELlO, E. F. C.; LIMA, S. S.; NOBRE, C. P.; CORREIA, M. E. F.; RESENDE, A. S. O uso de sistemas agroflorestais diversificados na restauração florestal na Mata Atlântica. Ciência Florestal, Santa Maria, v. 29, n. 2, p. 632-648, 2019.

MARTINS, K. G.; MARQUES, M. C. M.; SANTOS, E.; MARQUES, R. Effects of soil conditions on the diversity of tropical forests across a successional gradient. Forest Ecology and Management, Amsterdam, v. 349 , p. 4 $11,2015$.

POMPEO, P. N.; SANTOS, M. A. B.; BIASI, J. P.; SIQUEIRA, S. F.; ROSA, M. G.; BARETTA, C. R. D. M.; BARETTA, D. Fauna e sua relação com atributos edáficos em Lages, Santa Catarina - Brasil. Scientia Agraria, Curitiba, v. 17, n. 1, p. 42 - 51, 2016.

QASEM, J. R. Nutrient accumulation by weeds and their associated vegetable crops. Journal of Horticultural Sciences, Bangalore, v. 67, n. 2, p. 189 - 195, 1992.

SCHEMBERGUE, A.; CUNHA, D. A.; CARLOS, S. M.; PIRES, M. V.; FARIA, R. M. Sistemas agroflorestais como estratégia de adaptação aos desafios das mudanças climáticas no Brasil. Revista de Economia e Sociologia Rural, Brasília, v. 55, n. 1, p. 9 - 30, 2017.

SOUZA, M. C. S.; PIÑA-RODRIGUES, F. C. M. Desenvolvimento de espécies arbóreas em sistemas agroflorestais para recuperação de áreas degradadas na Floresta Ombrófila Densa, Paraty, RJ. Revista Árvore, Viçosa, v. 37, n. 1, p. 89 - 98, 2013. 